\title{
Root Trifurcation of Upper Permanent Second Molars: Anatomical Aspects of Clinical Interest
}

\author{
Trifurcación de la Raíz de Segundos Molares Permanentes: \\ Aspectos Anatómicos de Interés Clínico
}

"Fabiano Jeremias; " Lourdes Santos-Pinto \& **Hélio Ferraz Porciúncula

JEREMIAS, F.; SANTOS-PINTO, L. \& PORCIÚNCULA, H. F. Root trifurcation of upper permanent second molars: anatomical aspects of clinical interest. Int. J. Morphol., 27(3):649-653, 2009.

SUMMARY: The aim of this study was to analyze the relationship among the point of greatest depression on the root trifurcation floor and the furcation openings of the maxillary second molars. Sixty human extracted upper permanent second molars were analyzed and the furcation area were measured using a vertical calliper, and the values regarding the point of deepest depression were recorded. The results showed that the deepest depression in the trifurcation floor of the roots is centrally situated in $11.7 \%$ of the cases, whereas $88.3 \%$ involve mesial-buccal and distal-buccal roots. The distal furcation (F3) had the largest distance from the point of deepest depression in the trifurcation floor (A), followed by the buccal (F1) and mesial (F2) furcations when point A was below their respective openings. On the other hand, the medial furcation (F2) had the largest distance from point A, followed by distal (F3) and buccal (F1) furcations when point A was above their respective openings.

KEY WORDS: Molar; Odontometry; Furcation.

\section{INTRODUCTION}

It is common to observe a high index of root exposure resulting from the progression of periodontal disease affecting multi-rooted teeth, which also exposes trifurcation and its floor. There is a greater loss of periodontal root insertion compared to other parts of the tooth when the periodontal pocket reaches the furcation region, for it is much more difficult to control the bacterial plaque in this region (Waerhaugh, 1980). The concavities and other anatomical structures existing in the furcation region of upper and lower molars favour the retention of bacterial plaque, making its removal almost impossible for the patient. In addition, the upper second molars are more likely to develop periodontal complications due to the difficult access to their furcations (Hou et al., 1994; Paolantonio et al., 1992). This fact is further complicated when the furcation region is progressively involved in the periodontal disease (Hou et al., 2005).

The unsuccessful treatment of posterior teeth has been attributed to the presence of both retention niches, mainly regarding the maxillary teeth (McFall, 1982), and root crests in the depressions surrounding the regions of bifurcation or trifurcation (Gher \& Dunlap, 1985; Svärdström \& Wennström, 1988).

The existence of pathology in the furcation region is the result of multiple factors such as traumatic lesions, artificial crowns, and pulpal lesion with involvement of periodontal membrane through the accessory canals, or even a combination of these factors. A comparative study of upper and lower molars showed that the former teeth have more accessory canals, also greater in diameter, compared to the latter ones (Koenigs et al., 1974). Combined lesions emerge as the result of the interaction between endodontic and periodontal diseases in the same tooth, regardless of the time of their onset (Meng, 1999).

With respect to furcation lesions, therefore, one can state that prevention should be the main objective and thus the practitioner should recognise the areas that can compromise the periodontal health. The anatomical

\footnotetext{
* Pediatric Dentistry and Orthodontics Department, Araraquara School of Dentistry, Brazil.

*** Morphology Department, Araraquara School of Dentistry, Brazil.
} 
characteristics of the upper molars are rich in details and suffer variations mainly in relation to their roots, thus affecting the morphology of trifurcation with significant anatomical variations that can determine the topography of the trifurcation floor.

By considering the importance of knowing both variations in dental anatomy and odontological treatment, the purpose of the present work is to identify the point of deepest depression in the trifurcation floor of human upper permanent second molars and to establish measurements from this point to buccal, mesial, and distal furcation openings.

\section{MATERIAL AND METHOD}

Sixty human extracted upper permanent second molars, whose region under study was anatomically sound, were selected from the human tooth bank of the Discipline of Anatomy in the Department of Morphology of the Faculty of Dentristry- UNESP. The teeth were submitted to a cleaning process using curette for scraping, $2 \%$ muriatic acid, ultrasound and water jet, and sodium bicarbonate.

The crowns of the teeth were vertically inserted into self-polymerising acrylic resin during the plastic phase and then placed between the cursors of a vertical positioner. The cursors were moved until touching tangentially the dental surfaces and then held in their position while the resin was curing. The vertical positioner, which was mounted onto the base of the digital calliper, had a needle-shaped rod that was placed equidistantly between the roots in order to guide the verticalisation of the tooth (Fig. 1).

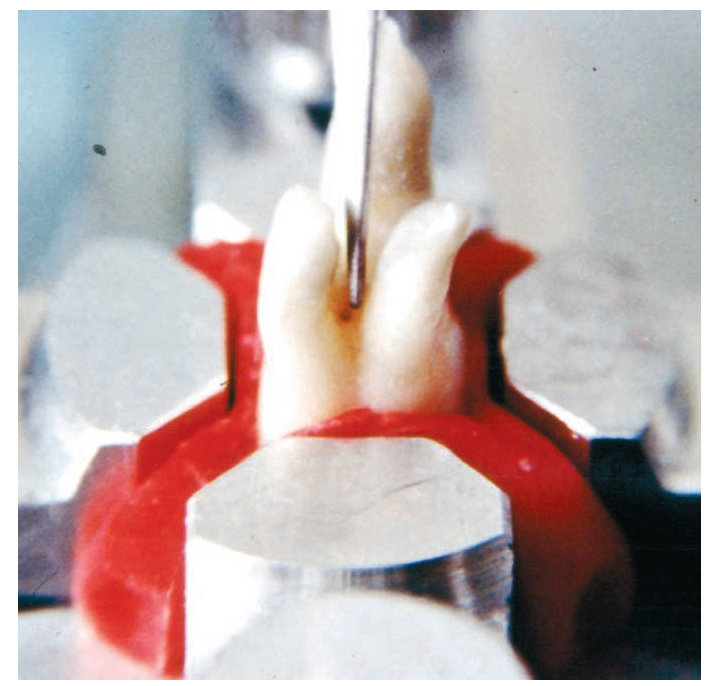

Fig. 1. Verticalisation of the tooth.
The tooth/resin block was centralised and fixed inside the central opening of an aluminium matrix measuring 3.0 $\mathrm{cm} \times 2.0 \mathrm{~cm}$, with divergence of 5 degrees, which was supported on a flat glass plate. Next, the whole set was entirely involved by another amount of acrylic resin (Fig. 2). After preparing all the blocks, marks corresponding to

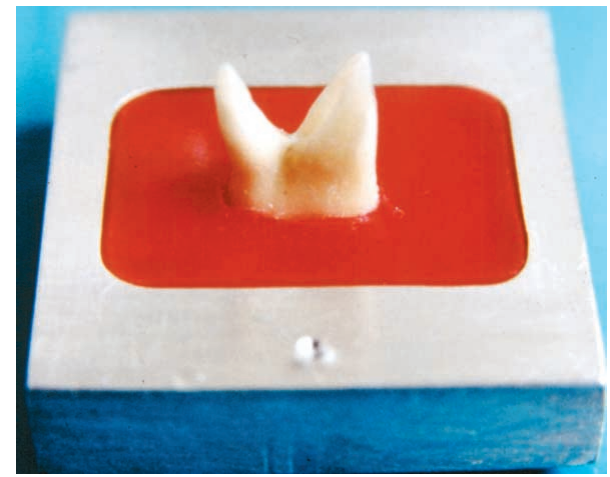

Fig. 2. Final phase of insertion: attachment of aluminium matrix to glass plate and application of resin at fluid phase.

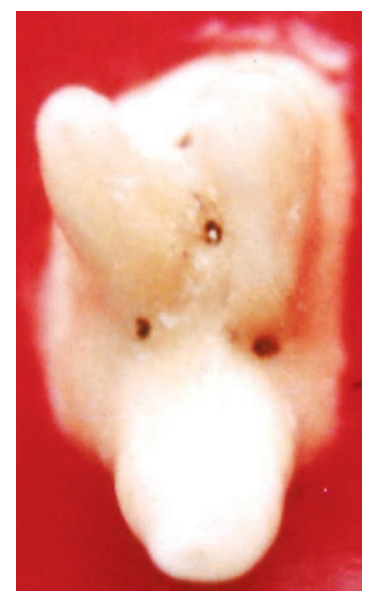

Fig. 3. Identification of points $\mathrm{A}, \mathrm{F} 1, \mathrm{~F} 2$, and $\mathrm{F} 3$ by marking them with a pencil.

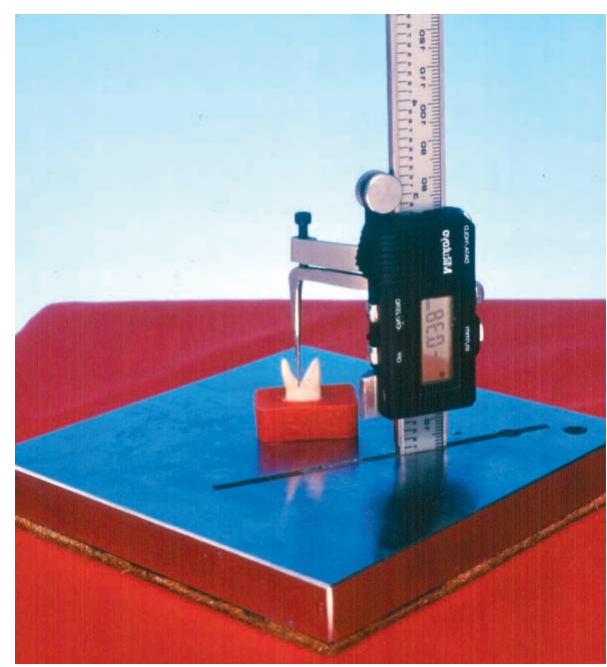

Fig. 4. Needle tip of the calliper touching the marked points. 
the openings of buccal (F1), mesial (F2), and distal (F3) furcations as well as the point of deepest depression in the trifurcation floor (A) were made in order to identify them (Fig. 3). A surgery microscope (model 320 - Karl Zeiss Jena, Germany) was used to such an identification procedure. Also, the distances A-F1, A-F2, and A-F3 were measured by using a vertical calliper, and the values regarding the point of deepest depression (A) were recorded whenever they were either below or above the furcation openings (Fig. 4). A previously trained investigator performed the measurement step twice in which a Kappa coefficient of 0.85 was achieved. For statistical analysis, the student t-test was employed at a significance level of $5 \%$.

\section{RESULTS}

The depression in the trifurcation floor (A) of human extracted upper permanent second molars was found centrally in $11.7 \%$ of the cases, whereas $88.3 \%$ involve mesial-buccal and distal-buccal roots.

The measurements of the distances from the point of deepest depression in the trifurcation floor (A) to the buccal (F1), mesial (F2), and distal (F3) furcation openings are described in Table I, demonstrating that such distances are statistically similar $(\mathrm{P}>0.05)$ when the point of deepest depression (A) was either below or above the furcation openings.

Table I. Frequency, mean (Student t-test), and standard deviation (SD) regarding the distance from point A to buccal (F1), mesial (F2), and distal (F3) furcations in human upper permanent second molars.

\begin{tabular}{lccc}
\hline \multicolumn{1}{c}{ Situation } & \% & Mean & SD \\
\hline A down F1 & 73 & 0.47 & 0.478 \\
A up F1 & 27 & 0.30 & 0.222 \\
A down F2 & 28 & 0.43 & 0.440 \\
A up F2 & 72 & 0.60 & 0.431 \\
A down F3 & 48 & 0.55 & 0.423 \\
A up F3 & 52 & 0.45 & 0.316 \\
\hline
\end{tabular}

\section{DISCUSSION}

There is an increased emergence of inaccessible areas when the concavities of the trifurcation floor are affected by localised periodontal disease, which allows bacteria to proliferate and limits the therapeutic instrumentation (Svärdström \& Wennström), eventually resulting in further loss of periodontal attachment (Waerhaugh).
The analysis based on furcation probe is often deceitful because the small opening being perceived is not always an evidence of the actual size of the existing space (Svärdström \& Wennström). The presence of arch-shaped concavities in the bifurcation region of lower molars was reported (Gher \& Dunlap). The present work found a similar situation regarding the trifurcation floor of upper permanent second molars in which $88.3 \%$ of the cases showed depression located between mesial-buccal (MB) and distal-buccal (DB) roots, whereas $11.7 \%$ had depression located at the centre of the trifurcation. This depression, because of its characteristics, can be considered like an almost inaccessible retention niche that makes removal and control of bacterial plaque very difficult (Carvalho et al., 1989), thus being partially responsible for the development of local periodontal lesions (Heasman \& Smith, 1988).

The depression occurring between mesial-buccal and distal-buccal roots supports the affirmation (Ross \& Thompson, 1980) that periodontal damage is more severe in upper molars. In addition, other studies (Hou et al., 1994) show that second premolars are more likely to have periodontal complications due to the difficult access to their bifurcations.

Studies involving specifically the trifurcation region of upper second molars are scarce in the literature. One can observe only some studies on permanent molars in which morphometric analyses of the opening region of the trifurcation are manually carried out (Santana et al., 2004) through imaging techniques (Plagmann et al., 2000) and microscopy methods (Paolantonio et al., 1998). As a result, we found no report whose results could be compared to those found in the present study. The mean distances from the point of deepest depression (A) to the openings of buccal (F1), mesial (F2), and distal (F3) furcations were, respectively, $0.47 \mathrm{~mm}, 0.43 \mathrm{~mm}$, and $0.55 \mathrm{~mm}$. However, when point A was above the level of furcation openings, the mean distances were $0.30 \mathrm{~mm}(\mathrm{~F} 1), 0.60 \mathrm{~mm}(\mathrm{~F} 2)$. and $0.45 \mathrm{~mm}(\mathrm{~F} 3)$.

Porciúncula (2001) who had assessed 200 upper molars in which half were second molars, found mean distances from the cement-enamel junction (CEJ) to the furcation openings and concluded that the smaller distances were those involving buccal $(3.03 \mathrm{~mm})$ and distal $(3.73 \mathrm{~mm})$ furcations. Considering these distances for localised periodontal disease, it is possible that the buccal furcation can be precociously compromised because it is nearer the CEJ $(3.03 \mathrm{~mm})$ and above the point $\mathrm{A}$, with a mean distance of $0.47 \mathrm{~mm}$ in $73 \%$ of the cases. Although such a distance is apparently not large, it characterises a significant retention niche. In addition, the dimensions regarding the buccal furcation make therapeutic instrumentation difficult. 
By analysing the mesial furcation (F2), one can observe a position inversion in relation to the buccal furcation as the mesial opening is below the point $\mathrm{A}$, with a mean distance of $0.60 \mathrm{~mm}$ in $72 \%$ of the cases. According to Porciúncula, therefore, the mesial furcation has the largest distance between its opening and CEJ $(4.69 \mathrm{~mm})$, which probably reduces the development of local periodontal lesions compared to buccal and distal furcations. However, the proximal furcations, if involved, can have an extremely unfavourable prognosis due to their localisation, mainly when a non-surgical periodontal treatment is performed (Ribeiro et al., 2007).

The results regarding the distal furcation (F3) show that its position in relation to point $\mathrm{A}$ is not so discrepant compared to buccal and mesial furcations, since the mean distances below and above the point A were close to, respectively, $0.45 \mathrm{~mm}(52 \%)$ and $0.55 \mathrm{~mm}(48 \%)$. However, it is important to emphasise that even in a smaller percentage (48\%), the distance from point $\mathrm{A}$ to the distal furcation opening (F3) had the largest value $(0.55 \mathrm{~mm})$ compared to the buccal and mesial furcations situated above point A. By considering the earlier results (Porciúncula), one can observer that the distance from CEJ to the distal furcation opening was $3.73 \mathrm{~mm}$, thus making it the second most probable furcation to be involved during the development of localised periodontal disease. Also, the distal furcation are more likely to favour the retention of bacteria because of its position in relation to point $\mathrm{A}$.

Taking into account the statements made by Abrams $\&$ Trachtenberg (1974) that distal furcation is like a precocious extension of periodontal pocket and that therapeutic interventions in some cases of trifurcation involvement require radicular amputation by removing the distal-buccal root (Majzoub \& Kon, 1992), the resulting anatomy is always unfavourable because the distal concavity makes hygienisation very difficult. Nevertheless, according to the results obtained in the present study, the largest distances from the point of deepest depression in the trifurcation $(\mathrm{A})$ were those involving the distal $(0.55 \mathrm{~mm})$ and buccal $(0.47 \mathrm{~mm})$ furcations, even when point A was below the respective openings. The data obtained by Porciúncula suggest that the distal-buccal root amputation is indicated in most cases, which is also corroborated in a study by Smukler \& Tagger (1976) in which $60 \%$ of the molars had their distal-buccal root amputated.

By recognising the importance of identifying precociously both presence and extension of the damage to periodontal support in the trifurcation region, we believe that the results obtained in the present study by means of precise measurements will effectively contribute to diagnosis, prevention, and treatment of the localised periodontal disease.

In conclusion, the distal furcation (F3) had the largest distance from the point of deepest depression in the trifurcation floor (A), followed by the buccal (F1) and mesial (F2) furcations when point A was below their respective openings. On the other hand, the medial furcation (F2) had the largest distance from point A, followed by distal (F3) and buccal (F1) furcations when point A was above their respective openings.

JEREMIAS, F.; SANTOS-PINTO, L. \& PORCIÚNCULA, H. F. Trifurcation de la raíz de segundos molares permanentes: aspectos anatómicos de interés clínico. Int. J. Morphol., 27(3):649-653, 2009.

RESUMEN: El presente estudio examinó la relación entre el punto de mayor depresión del suelo de la trifurcación de la raíz y la apertura de furcas en los segundos molares superiores. Sesenta segundos molares permanentes extraídos de humanos fueron analizados. El área de furca se midió utilizando un calibrador digital adaptado y valores sobre el punto de mayor depresión fueron registrados. Los resultados mostraron que la mayor depresión esta en el centro del suelo de las raíces en el 11,7\% de los casos, mientras que $88,3 \%$ cubren las raíces mesio-vestibular y disto-vestibular. El punto de mayor depresión en el suelo de la trifurcación (A) presentó la mayor distancia desde la bifurcación distal (F3), seguido por la vestibular (F1) y mesial (F2) cuando el punto estaba por debajo de sus respectivas aperturas. Además, la bifurcación mesial (F2) presentó la mayor distancia desde el punto A, seguido por distal (F3) y vestibular (F1), cuando el punto A estaba por encima de sus respectivas aperturas.

PALABRAS CLAVE: Molar; Odontometría; Furcación.

\section{REFERENCES}

Abrams, L. \& Trachtenberg, D. I. Hemisection: technique and restoration. Dent. Clin. North Am., 18:415-44, 1974.
Carvalho, J. C. M.; Tristão, G. C. \& Pustiglioni, F. E. A periodontia e a prótese. In: Saito, T. Preparos dentários funcionais. São Paulo, Santos, 1989. pp.47-81. 
Gher, M. E. \& Dunlap, R. W. Linear variation of the surface area of the maxillary first molar. J. Periodontol., $56(1): 39-43,1985$.

Heasman, P. A. \& Smith, D. G. The role of anatomy in the initiation and spread of periodontal disease. Dent. Update, 15(5):192-7, 1988.

Hou, G. L.; Hung, C. C.; Tsai, C. C. \& Weisgold, A. S. Topographic study of root trunk type on Chinese molars with Class III furcation involvements: molar type and furcation site. Int. J. Periodontics Restorative Dent., 25(2):173-9, 2005.

Hou, G. L.; Chen, S. F.; Wu, Y. M. \& Tsai, C. C. The topography of the furcation entrance in Chinese molars. J. Clin. Periodontol., 21:451-6, 1994.

Koenigs, J. F.; Brilliant, J. D. \& Foreman Jr, D. W. Preliminary scanning eletron microscope investigations of acessory foramina in the furcation areas of human molar teeth. Oral Surg., 38(5):772-82, 1974.

Majzoub, Z. \& Kon, S. Tooth morphology following root resection procedures in maxillary first molars. J. Periodontol., 63(4):290-6, 1992.

McFall, Jr. W. T. Tooth loss in 100 treated patients with periodontal disease. J. Periodontol., 53(9):539-49, 1982.

Meng, H. X. Periodontic-endodontic lesions. Ann. Periodontol., 4:84-90, 1999.

Paolantonio, M.; Centobeni, R.; Scogna, G. \& Di Murro, C. The anatomical characteristics of the root furcations in the molar teeth. Minerva Stomatol., 41(3):105-20, 1992.

Paolantonio, M.; di Placido, G.; Scarano, A. \& Piattelli, A. Molar root furcation: morphometric and morphologic analysis. Int. J. Periodontics Restorative Dent., 18(5):488-501, 1998.

Plagmann, H. C.; Holtorf, S. \& Kocher, T. A study on the imaging of complex furcation forms in upper and lower molars. J. Clin. Periodontol., 27(12):926-31, 2000.

Porciúncula, H. F. Estudo Biométrico das Furcas Radiculares Vestibular, Mesial e Distal dos Primeiros e Segundos Molares Superiores Permanentes de Humanos, SP. Dissertação (Livre-Docência em Anatomia). Araraquara, Universidade Estadual Paulista, 2001.

Ross, I. F. \& Thompson, Jr. R. H. Furcation involvement in maxillary and mandibular molars. J. Periodontol., 51(8):450-4, 1980.

Ribeiro, E. P.; Bittencourt, S.; Nociti, Jr. -F. H.; Sallum-, E. A.; Sallum, -A. W. \& Casati, M. Z. Comparative study of ultrasonic instrumentation for the non-surgical treatment of interproximal and non-interproximal furcation involvements. J. Periodontol., 78(2):224-30, 2007.

Santana, R. B.; Uzel, M. I.; Gusman, H.; Gunaydin, Y.; Jones, J. A. \& Leone, C. W. Morphometric analysis of the furcation anatomy of mandibular molars. J. Periodontol., 75(6):824-9, 2004.

Smukler, H. \& Tagger, M. Vital root amputation. A clinical and histological study. J. Periodontol., 47(6):324-30, 1976.

Svärdström, G. \& Wennström, J. L. Furcation topography of the maxillary and mandibular first molars. J. Clin. Periodontol., 15(5):271-5, 1988.

Waerhaugh, J. The furcation problem: etiology, pathogenesis, diagnosis, therapy and prognosis. J. Clin. Periodontol., 7(2):73-95, 1980 .

Correspondence to:

Lourdes Aparecida Martins dos Santos-Pinto

Pediatric Dentistry and Orthodontics Department

Araraquara School of Dentistry

Universidad Estadual São Paulo, BRASIL

Rua Humaitá, 1680, Araraquara-SP CEP: 14801-903

E-mail: Ispinto@foar.unesp.br

Received: 24-11-2008

Accepted: 31-03-2009 
